\title{
Long memory and data frequency in financial markets
}

\section{Guglielmo Maria Caporale, Luis Gil-Alana \& Alex Plastun}

To cite this article: Guglielmo Maria Caporale, Luis Gil-Alana \& Alex Plastun (2019) Long memory and data frequency in financial markets, Journal of Statistical Computation and Simulation, 89:10, 1763-1779, DOI: 10.1080/00949655.2019.1599377

To link to this article: https://doi.org/10.1080/00949655.2019.1599377 (c) 2019 The Author(s). Published by Informa
UK Limited, trading as Taylor \& Francis Group

曲 Published online: 03 Apr 2019.

Submit your article to this journal

Шll Article views: 2219

Q View related articles

View Crossmark data $\nearrow$

Citing articles: 7 View citing articles 


\title{
Long memory and data frequency in financial markets
}

\author{
Guglielmo Maria Caporale ${ }^{a, b}$, Luis Gil-Alana ${ }^{c}$ and Alex Plastun (D) \\ ${ }^{a}$ Department of Economics and Finance, Brunel University London, London, UK; ${ }^{b} \mathrm{CESifo}$ and DIW Berlin, \\ Berlin, Germany; ${ }^{\mathrm{C}}$ Department of Economics, University of Navarra, Pamplona, Spain; ${ }^{\mathrm{d}}$ Department of \\ Economics, Sumy State University, Sumy, Ukraine
}

\begin{abstract}
This paper investigates persistence in financial time series at three different frequencies (daily, weekly and monthly). The analysis is carried out for various financial markets (stock markets, FOREX, commodity markets) over the period from 2000 to 2016 using two different long memory approaches ( $R / S$ analysis and fractional integration) for robustness purposes. The results indicate that persistence is higher at lower frequencies, for both returns and their volatility. This is true of the stock markets (both developed and emerging) and partially of the FOREX and commodity markets examined. Such evidence against the random walk behaviour implies predictability and is inconsistent with the Efficient Market Hypothesis (EMH), since abnormal profits can be made using trading strategies based on trend analysis.
\end{abstract}

\section{ARTICLE HISTORY}

Received 22 June 2018

Accepted 21 March 2019

\section{KEYWORDS}

Persistence; long memory; $\mathrm{R} / \mathrm{S}$ analysis; fractional integration

\section{JEL CLASSIFICATIONS} $\mathrm{C} 22 ; \mathrm{G} 12$

\section{Introduction}

The Efficient Market Hypothesis (EMH), according to which asset prices should follow a random walk and therefore not exhibit long memory (see [1]) has been for decades the dominant paradigm in financial economics. However, the available empirical evidence is quite mixed. Mandelbrot [2], Greene and Fielitz [3], Booth et al. [4], Helms et al. [5], Mynhardt et al. [6], Abbritti et al. [7], Urquhart [8], Nystrup et al. [9], Bariviera [10], Niu and Wang [11], Caporale et al. [12], Phillip et al. [13] all provided evidence of long memory behaviour in financial markets. By contrast, Lo [14], Jacobsen [15], Berg and Lyhagen [16], Crato and Ray [17], Batten et al. [18] and Serletis and Rosenberg [19], Lu and Perron [20] did not find long-memory properties in financial series. A possible reason for such different findings is that the degree of persistence might change over time as argued by Corazza and Malliaris [21], Glenn [22] and Bennett and Gartenberg [23].

The present study aims to examine this possible explanation by estimating persistence in financial time series at three different frequencies (daily, weekly and monthly). The analysis is carried out for various financial markets (stock markets, FOREX, commodity markets), for both returns and their volatility, over the period from 2000 to 2016 using two different long memory approaches (R/S analysis with the Hurst exponent method and fractional

CONTACT Guglielmo Maria Caporale caporale@brunel.ac.uk Department of Economics and Finance, Brunel University London, London UB8 3PH, UK 
integration) for robustness purposes. The hypothesis to be tested is that persistence is higher at lower frequencies.

The layout of the paper is the following. Section 2 describes the data and outlines the empirical methodology. Section 3 presents the empirical results. Section 4 provides some concluding remarks.

\section{Data and methodology}

The R/S method was originally applied by Hurst [24] in hydrological research and improved by Mandelbrot and Wallis [25], Mandelbrot [2], Peters [26,27] and Lo [14], analysing the fractal nature of financial markets. Compared with other approaches it is relatively simple and suitable for programming as well as visual interpretation.

For each sub-period range $\mathrm{R}$ (the difference between the maximum and minimum index within the sub-period), the standard deviation $S$ and their average ratio are calculated. The length of the sub-period is increased and the calculation repeated until the size of the subperiod is equal to that of the original series. As a result, each sub-period is determined by the average value of $\mathrm{R} / \mathrm{S}$. The least square method is applied to these values and a regression is run, obtaining an estimate of the angle of the regression line. This estimate is a measure of the Hurst exponent, which is an indicator of market persistence. More details are provided below.

1. We start with a time series of length $M$ and transform it into one of length $N=M-1$ using logs and converting prices into returns (or volatility):

$$
N_{i}=\log \left(\frac{Y_{t+1}}{Y_{t}}\right), \quad t=1,2,3, \ldots(M-1) .
$$

2. We divide this period into contiguous $A$ sub-periods with length $\mathrm{n}$, so that $A_{n}=N$, then we identify each sub-period as $I_{a}$, given the fact that $a=1,2,3, \ldots, A$. Each element $I_{a}$ is represented as $N_{k}$ with $k=1,2,3, \ldots, N$. For each $I_{a}$ with length $n$ the average $e_{a}$ is defined as

$$
e_{a}=\frac{1}{n} \sum_{k=1}^{n} N_{k, a}, \quad k=1,2,3, \ldots, N, \quad a=1,2,3, \ldots, A
$$

3. Accumulated deviations $X_{k, a}$ from the average $e_{a}$ for each sub-period $I_{a}$ are defined as

$$
X_{k, a}=\sum_{i=1}^{k}\left(N_{i, a}-e_{a}\right)
$$

The range is defined as the maximum index $X_{k, a}$ minus the minimum $X_{k, a}$, within each sub-period $\left(I_{a}\right)$ :

$$
R_{I a}=\max \left(X_{k, a}\right)-\min \left(X_{k, a}\right), \quad 1 \leq k \leq n .
$$

4. The standard deviation $S_{I a}$ is calculated for each sub-period $I_{a}$ :

$$
S_{I a}=\left(\left(\frac{1}{n}\right) \sum_{k=1}^{n}\left(N_{k, a}-e_{a}\right)^{2}\right)^{0,5} .
$$


5. Each range $R_{I a}$ is normalized by dividing by the corresponding $S_{I a}$. Therefore, the renormalized scale during each sub-period $I_{a}$ is $R_{I a} / S_{I a}$. In the step 2 above, we obtained adjacent sub-periods of length $\mathrm{n}$. Thus, the average $\mathrm{R} / \mathrm{S}$ for length $n$ is defined as

$$
(R / S)_{n}=(1 / A) \sum_{i=1}^{A}\left(R_{I a} / S_{I a}\right) .
$$

6. The length $n$ is increased to the next higher level, $(M-1) / n$, and must be an integer number. In this case, we use $n$-indexes that include the initial and ending points of the time series, and Steps $1-6$ are repeated until $n=(M-1) / 2$.

7. Now we can use least square to estimate the equation $\log (R / S)=\log (c)+H \log (n)$. The angle of the regression line is an estimate of the Hurst exponent $H$. This can be defined over the interval $[0,1]$, and is calculated within the boundaries specified below (for more detailed information see Appendix 3):

- $0 \leq H<0.5$ - the data are fractal, the EMH is not confirmed, the distribution has fat tails, the series are anti-persistent, returns are negatively correlated, there is pink noise with frequent changes in the direction of price movements, trading in the market is riskier for individual participants.

- $H=0.5$ - the data are random, the EMH is confirmed, asset prices follow a random Brownian motion (Wiener process), the series are normally distributed, returns are uncorrelated (no memory in the series), they are a white noise, traders cannot «beat» the market using any trading strategy.

- $0.5<H \leq 1$ - the data are fractal, the EMH is not confirmed, the distribution has fat tails, the series are persistent, returns are highly correlated, there is black noise and a trend in the market.

There are different approaches to calculate the Hurst exponent (see Appendix 1). In most cases, detrended fluctuation analysis (DFA) produces the best results [28,29], but for financial series the R/S analysis seems to be the most appropriate (see Appendix 2), and therefore is used here. The interpretation of the Hurst exponent is as follows: the higher it is, the lower the efficiency of the market is [30].

In order to analyse persistence, we also estimate parametric/semiparametric fractional integration or $I(d)$ models. This type of models were originally proposed by Granger [31] and Granger and Joyeux [32]; they were motivated by the observation that the estimated spectrum in many aggregated series exhibits a large value at the zero frequency, which is consistent with nonstationary behaviour; however, this becomes close to zero after differencing, which suggests over-differentiation. Examples of applications of fractional integration to financial time series data can be found in Barkoulas and Baum [33], Barkoulas et al. [34], Sadique and Silvapulle [35], Henry [36], Baillie et al. [37], Caporale and Gil-Alana [38] and Al-Shboul and Anwar [39].

In this study we adopt the following specification:

$$
(1-L)^{d} x_{t}=u_{t}, \quad t=0, \quad \pm 1, \ldots,
$$

where $\mathrm{d}$ can be any real value, $\mathrm{L}$ is the lag-operator $\left(L x_{t}=x_{t-1}\right)$ and $u_{t}$ is $I(0)$, defined for our purposes as a covariance stationary process with a spectral density function that is 
positive and finite at the zero frequency. Note that $H$ and $d$ are related through the equality $H=d-0.5$.

In the semiparametric model, no specification is assumed for $\mathrm{u}_{\mathrm{t}}$. The most common approach is based on the log-periodogram (see [40]). This method was later extended and improved by many authors including Künsch [41], Robinson [42], Hurvich and Ray [43], Velasco [44,45] and Shimotsu and Phillips [46]. In this paper, however, we will employ instead another semiparametric method, which is essentially a local 'Whittle estimator' defined in the frequency domain using a band of high frequencies that degenerates to zero. The estimator is implicitly defined by

$$
\begin{aligned}
& \hat{d}=\arg \min { }_{d}\left(\log \overline{C(d)}-2 d \frac{1}{m} \sum_{s=1}^{m} \log \lambda_{s}\right), \\
& \overline{C(d)}=\frac{1}{m} \sum_{s=1}^{m} I\left(\lambda_{s}\right) \lambda_{s}^{2 d}, \quad \lambda_{s}=\frac{2 \pi s}{T}, \quad \frac{m}{T} \rightarrow 0,
\end{aligned}
$$

where $m$ is a bandwidth parameter, and $I\left(\lambda_{s}\right)$ is the periodogram of the raw time series, $x_{t}$, given by

$$
I\left(\lambda_{s}\right)=\frac{1}{2 \pi T}\left|\sum_{t=1}^{T} x_{t} e^{i \lambda_{s} t}\right|^{2},
$$

and $d \in(-0.5,0.5)$. Under finiteness of the fourth moment and other mild conditions, Robinson [47] proved that:

$$
\sqrt{m}\left(\hat{d}-d_{o}\right) \rightarrow_{d} N(0,1 / 4) \quad \text { as } T \rightarrow \infty,
$$

where $d_{o}$ is the true value of $\mathrm{d}$. This estimator is robust to a certain degree of conditional heteroscedasticity and is more efficient than other more recent semiparametric competitors. Recent refinements of this procedure can be found in Velasco [48], Velasco and Robinson [49], Phillips and Shimotsu [50,51], Abadir et al. [52] and Shao [53].

Estimating $d$ parametrically along with the other model parameters can be done in the frequency domain or in the time domain. In the former, Sowell [54] analysed the exact maximum likelihood estimator of the parameters of the ARFIMA model, using a recursive procedure that allows a quick evaluation of the likelihood function. Other parametric methods for estimating $d$ based on the frequency domain were proposed by Fox and Taqqu [55] and Dahlhaus [56] (see also [57] and [58] for Wald and LM parametric tests based on the Whittle function).

We analyse both returns and their volatility. Returns are computed as follows:

$$
R_{i}=\left(\frac{\text { Close }_{i}}{\operatorname{Open}_{i}}-1\right) \times 100 \%,
$$

where $R_{i}$ - returns on the $i$ th day inpercentage terms; Open ${ }_{i}$ - open price on the $i$ th day; Close $_{i}$ - close price on the $i$ th day.

Volatility is defined as follows:

$$
V_{i}=\left(\frac{\operatorname{High}_{i}}{\text { Low }_{i}}-1\right) \times 100 \%,
$$

where $V_{i}$ - volatility on the $i$ th day in percentage terms; High $_{i}$ - maximum price on the $i$ th day; Low $_{i}$ - minimum price on the $i$ th day. 
Data from different financial markets (stock markets, FOREX and commodity markets) are used for the empirical analysis. Specifically, the following financial series are analysed: the Dow Jones Index (the data source is Dow Jones \& Company, https://www.dowjones.com/), the FTSE index (the data source is FTSE Russell, https://www.ftserussell.com/), the NIKKEI (the data source is Nikkei Inc., https://indexes.nikkei.co.jp/en/nkave/archives/data) for the developed stock markets (U.S.A., Great Britain and Japan respectively) and MICEX (the data source is Moskow Exchange, https://www.moex.com/) and PFTS (the data source is PFTS Exchange, https://pfts.us) for the emerging ones (for Russia and Ukraine respectively); the EUR/USD and USD/JPY exchange rates for the FOREX (the data source is MetaQuotes Software Corp.); Gold and Oil futures for the commodity markets (the data source is MetaQuotes Software Corp.). The sample period goes from 2000 to 2016 except for PFTS, for which series it starts in 2001. Descriptive statistics of the data are presented in Appendix 7.

\section{Empirical results}

The results of the R/S analysis for the various financial markets are presented in Appendix 4 . As can be seen, in the case of stock markets, the returns are more persistent the lower the frequency is. The results for the commodity markets are more mixed. In the case of gold higher persistence is still found at lower frequencies, but in the case of oil the Hurst exponent is the same at the daily and monthly frequency, whilst it is higher at the weekly frequency, suggesting an increase in the degree of persistence at lower frequencies. In the FOREX, persistence of returns is the same across frequencies, except for the USDJPY exchange rate, whose monthly returns are much more persistent then daily ones.

Overall it appears that the evidence for returns is most consistent with the EMH in the case of the FOREX and least so in the case of stock markets. The observation that persistence is higher at lower frequencies suggests that for prediction purposes using data at such frequencies is most useful. Whilst most daily series follow a random walk, monthly ones exhibit long-memory properties seemingly inconsistent with the EMH. Concerning the results for volatility, we find that the daily series also follow a random walk, whilst the weekly and monthly ones have long memory and are persistent, this being true of the stock and FOREX markets, whilst in the case of the commodity markets persistence at the daily frequency is replaced by anti-persistence at the weekly and monthly ones. This suggests that markets are noisy and that abnormal profits can be made through volatility trading by using specific option trading strategies (butterfly, straddle, strangle, iron condor, etc.).

The results for the fractional integration methods are presented in Appendix 5. First, we display in Table A5 the estimates of $d$ along with their corresponding 95\% confidence interval using a parametric method [57]. As before, the hypothesis that persistence is higher at lower frequencies cannot be rejected for the stock market series, since the estimated value of $d$ increases as one moves from daily to weekly and monthly data. By contrast, no significant differences across frequencies emerge for the FOREX and commodity markets. As for the volatility series, there is evidence of long memory (i.e. $d>0$ ) in all cases but no evidence of a higher degree of persistence at lower frequencies.

Appendix 6 focuses on the semiparametric approach, first for the return series (Table A6) and then for their volatilities (Table A7). We find again higher persistence at lower frequencies for the stock markets considered, but not the FOREX and the commodity ones. 


\section{Conclusions}

This paper uses both the Hurst exponent and parametric/semiparametric fractional integration methods to analyse the long-memory properties of financial data at different frequencies. The hypothesis of interest is that lower frequencies correspond to higher persistence. Daily, weekly and monthly (return and volatility) series from different financial markets (stock markets, FOREX and commodity markets) are analysed for the period from 2000 to 2016.

The findings suggest that in the case of returns daily data usually follow a random walk, consistently with the EMH, whilst at lower frequencies persistence is higher, which implies predictability and the possibility of making abnormal profits using appropriate trading strategies. This is true for the stock markets (both developed and emerging) and partially for the FOREX and commodity market considered. The results for the volatility series in the case of the stock market are similar to those for returns, namely lower frequencies are associated to higher persistence, whilst in the commodity markets lower-frequency data are characterized by anti-persistence.

Very similar results are obtained when using fractional integration methods, be they parametric or semiparametric: for returns the estimated value of $d$ is higher at lower frequencies for the stock markets analysed, though basically the same across frequencies for the other markets examined. However, for the FOREX and commodity markets, we do not find significant differences across frequencies. For the volatility series, the observed long-memory properties (i.e. $d>0$ ) are also unaffected by the data frequency. Obviously in all cases when persistence is higher at lower frequencies there exist profit opportunities (through appropriately designed trading strategies) that are inconsistent with market efficiency.

Persistence implies predictability of asset prices, which is inconsistent with the Efficient Market Hypothesis (EMH) and the Random Walk Hypothesis (RWH). Our results at both the daily and weekly frequency indicate a rather low degree of persistence and price behaviour close to a random walk without a trend, which suggests market efficiency. However, this is not the case at the monthly frequency, especially in the case of the stock market, in both developed and emerging economies, with prices appearing to be highly persistent and exhibiting a trend, in contrast to the implications of the EMH. These are important findings since they represent evidence in favour of the possibility of generating abnormal profits by adopting trading strategies based on trend analysis, which appears to be most effective at the monthly frequency.

\section{Acknowledgements}

Comments from the Editor and two anonymous reviewers are gratefully acknowledged.

\section{Disclosure statement}

No potential conflict of interest was reported by the authors.

\section{Funding}

Luis A. Gil-Alana gratefully acknowledges financial support from the Ministerio de Ciencia y Tecnología [grant number ECO2017-85503-R]. Alex Plastun gratefully acknowledges financial support from the Ministry of Education and Science of Ukraine [grant number 0117U003936]. 


\section{ORCID}

Alex Plastun (iD http://orcid.org/0000-0001-8208-7135

\section{References}

[1] Fama E. Efficient Capital markets: A review of Theory and empirical Work. J Financ. 1970;25:383-417.

[2] Mandelbrot B. Statistical methodology for nonperiodic cycles: from the covariance to Rs analysis. Annals of Economic and Social Measurement. 1972;1:259-290.

[3] Greene M, Fielitz B. Long-term dependence in common stock returns. J Financ Econ. 1977;4:339-349.

[4] Booth G, Kaen F, Koveos P. R/S analysis of foreign exchange rates under two international monetary regimes. J Monet Econ. 1982;10(3):407-415.

[5] Helms B, Kaen F, Rosenman R. Memory in commodity futures contracts. J Futures Markets. 1984;4:559-567.

[6] Mynhardt R, Plastun A, Makarenko I. Behavior of financial markets efficiency during the financial market crisis: 2007-2009. Corp Ownership Control. 2014;11(2):473-488.

[7] Abbritti M, Gil-Alana LA, Lovcha Y, et al. Term structure persistence. J Financ Economet. 2016;14(2): 331-352.

[8] Urquhart A. The Inefficiency of Bitcoin. Econ Lett. 2016;148:80-82.

[9] Nystrup P, Madsen H, Lindström E. Long memory in financial time series and hidden Markov models with time varying parameters. J Forecast. 2017;36(8):989-1002.

[10] Bariviera AF. The inefficiency of Bitcoin revisited: A dynamic approach. Econ Lett. 2017;161:1-4.

[11] Niu H, Wang J. Volatility clustering and long memory of financial time series and financial price model. Digit Signal Process. 2013;23(2):489-498.

[12] Caporale GM, Gil-Alana L, Plastun A. Persistence in the cryptocurrency market. Res Int Bus Financ. 2018;46:141-148.

[13] Phillip A, Chan JSK, Peiris MS. A new look at Cryptocurrencies. Econ Lett. 2018;163:6-9.

[14] Lo A. Long-term memory in stock market prices. Econometrica. 1991;59:1279-1313.

[15] Jacobsen B. Are Stock returns long term Dependent? some empirical evidence. Journal of International financial markets. Institutions and Money. 1995;5(2/3):37-52.

[16] Berg L, Lyhagen J. Short and long Run Dependence in Swedish Stock returns. Appl Financ Econ. 1998;8(4):435-443.

[17] Crato N, Ray B. Memory in returns and volatilities of commodity futures' Contracts. J Futures Markets. 2000;20(6):525-543.

[18] Batten J, Ellis C, Fetherston T. Return Anomalies on the Nikkei: Are they statistical Illusions? Chaos Soliton Fract. 2005;23(4):1125-1136.

[19] Serletis A, Rosenberg A. The Hurst exponent in energy futures prices. Physica A. 2007;380:325-332.

[20] Lu YK, Perron P. Modeling and forecasting stock return volatility using a random level shift model. J Empir Financ. 2010;17:138-156.

[21] Corazza M, Malliaris A. Multifractality in Foreign Currency markets. Multinational Financ J. 2002;6:65-98.

[22] Glenn L. On Randomness and the NASDAQ Composite, Working Paper; 2007Available from SSRN: http://ssrn.com/abstract $=1124991$.

[23] Bennett VM, Gartenberg CM. Changes in persistence of performance over time. Duke I\&E Res Pap Number. 2016;41:2016-2041.

[24] Hurst H. (1951). Long-term Storage of Reservoirs. Transactions of the American Society of Civil Engineers, 799 p.

[25] Mandelbrot B, Wallis JR. Computer experiments with fractional noises. Water Resour Res. 1969;5(228):909-918. 
[26] Peters E. Chaos and order in the Capital markets: A New View of Cycles, prices, and market volatility. New York (NY): John Wiley and Sons, Inc; 1991; p. 228.

[27] Peters E. Fractal market analysis: Applying Chaos Theory to Investment and Economics New York (NY): John Wiley \& Sons; 1994; p. 336.

[28] Weron R. Estimating long-range dependence: finite sample properties and confidence intervals. Physica A. 2002;312(1):285-299.

[29] Grech D, Mazur Z. Can one make any crash prediction in finance using the local Hurst exponent idea? Physica A. 2004;336:133-145.

[30] Cajueiro D, Tabak B. Ranking efficiency for emerging equity markets II. Chaos Soliton Fract. 2005;23:671-675.

[31] Granger C. Long memory relationships and the aggregation of dynamic models. J Econom. 1980;14:227-238.

[32] Granger C, Joyeux R. An introduction to long memory time series and fractionally differencing. J Time Ser Anal. 1980;1:15-29.

[33] Barkoulas J, Baum C. Long term dependence in stock returns. Econ Lett. 1996;53:253-259.

[34] Barkoulas J, Labys W, Onoche J. Fractional dynamics in international commodity prices. J Future Mark. 1997;17:161-189.

[35] Sadique S, Silvapulle P. Long-term memory in stock market returns: international evidence. Int J Financ Econ. 2001;6:59-67.

[36] Henry O. Long memory in stock returns. some international evidence. Appl Financ Econ. 2002;12:725-729.

[37] Baillie R, Han Y, Myers R, et al. Long memory models for daily and high frequency commodity future returns. J Future Mark. 2007;27:643-668.

[38] Caporale G, Gil-Alana L. Fractional cointegration and tests of prestng value models. Rev Financ Econ. 2004;13:245-258.

[39] Al-Shboul M, Anwar S. Fractional integration and daily stock market indices at Jordan's Amman stock exchange. N Am J Econ Financ. 2016, forthcoming.

[40] Geweke J, Porter-Hudak S. The estimation and application of long memory time series models. J Time Ser Anal. 1983;4:221-238.

[41] Künsch H. Discrimination between monotonic trends and long-range dependence. J Appl Probab. 1986;23:1025-1030.

[42] Robinson P. Log-periodogram regression of time series with long range dependence. Ann Stat. 1995a;23:1048-1072.

[43] Hurvich C, Ray B. Estimation of the memory parameter for nonstationary or noninvertible fractionally integrated processes. J Time Ser Anal. 1995;16:17-41.

[44] Velasco C. Nonstationary log-periodogram regression. J Econom. 1999a;91:325-371.

[45] Velasco C. Non-Gaussian log-periodogram regression. Econ Theory. 2000;16:44-79.

[46] Shimotsu K, Phillips P. Pooled Log periodogram regression. J Time Ser Anal. 2002;23:57-93.

[47] Robinson P. Gaussian semi-parametric estimation of long range dependence. Ann Stat. 1995b;23:1630-1661.

[48] Velasco C. Gaussian semiparametric estimation of nonstationary time series. J Time Ser Anal. 1999b;20:87-127.

[49] Velasco C, Robinson P. Whittle pseudo maximum likelihood estimation for nonstationary time series. J Am Stat Assoc. 2000;95:1229-1243.

[50] Phillips P, Shimotsu K. Local Whittle estimation in nonstationary and unit root cases. Ann Stat. 2004;32:656-692.

[51] Phillips P, Shimotsu K. Exact local Whittle estimation of fractional integration. Ann Stat. 2005;33:1890-1933.

[52] Abadir K, Distaso W, Giraitis L. Nonstationarity-extended local Whittle estimation. J Econom. 2007;141:1353-1384.

[53] Shao X. Nonstationarity-extended Whittle estimation. Econ Theory. 2010;26:1060-1087.

[54] Sowell F. Maximum likelihood estimation of stationary univariate fractionally integrated time series models. J Econom. 1992;53:165-188. 
[55] Fox R, Taqqu M. Large sample properties of parameter estimates for strongly dependent stationary Gaussian time series. Ann Stat. 1986;14:517-532.

[56] Dahlhaus R. Efficient parameter estimation for self-similar process. Ann Stat. 1989;17: 1749-1766.

[57] Robinson P. Efficient tests of nonstationary hypotheses. J Am Stat Assoc. 1994;89:1420-1437.

[58] Lobato I, Velasco C. Efficient Wald tests for fractional unit root. Econometrica. 2007;75(2): 575-589.

[59] Taqqu M, Teverosky W, Willinger W. Estimators for long-range dependence: an empirical study. Fractals. 1995;3(4):785-798.

[60] Kantelhardt J, Zschiegner S, Koscielny-Bunde E, et al. Multifractal detrended fluctuation analysis of nonstationary time series. Physica A. 2002;316:87-114.

[61] Couillard M, Davison M. A comment on measuring the Hurst exponent of financial time series. Physica A. 2005;348:404-418.

[62] Teverovsky V, Taqqu M, Willinger W. A critical look at Lo's modified R/S statistic. J Stat Plan Inference. 1999;80:211-227.

[63] Barunik J, Kristoufek L. On Hurst exponent estimation under heavy-tailed distributions. Physica A. 2010;389(18):3844-3855.

[64] Hja S, Lin Y. R/ S analysis of China Securities markets. Tsinghua Sci Technol. 2003;8(5):537-540.

[65] Lento C. A Synthesis of Technical analysis and fractal Geometry - evidence from the Dow Jones Industrial average Components. J Tech Anal. 2013;67:25-45.

[66] Onali E, Goddard J. Are European equity markets efficient? New evidence from fractal analysis Int Rev Financ Anal. 2011;20(2):59-67.

[67] Serletis A, Rosenberg A. Mean reversion in the US stock market. Chaos Soliton Fract. 2009;40:2007-2015.

[68] Ding Z, Granger C, Engle R. A long memory property of stock market returns and a new model. J Empir Financ. 1993;1:83-106.

\section{Appendices}

\section{Appendix 1}

Table A1. Methodology for the Hurst exponent calculations: general review.

\begin{tabular}{|c|c|c|}
\hline Author(s) & Methodology* & Results \\
\hline Taqqu et al. [59] & $\mathrm{R} / \mathrm{S}, \mathrm{DFA}$ & R/S overestimates Hurst exponent, DFA - underestimates. \\
\hline Weron [28] & $\mathrm{R} / \mathrm{S}, \mathrm{DFA}$ & DFA exceeds $\mathrm{R} / \mathrm{S}$ \\
\hline Kantelhardtetal [60] & MF-DFA & MF -DFA estimations are better than those from the R/S - analysis \\
\hline Couillard and Davison [61] & $\mathrm{R} / \mathrm{S}$ analysis & No long memory in financial data is detected. \\
\hline Grech and Mazur [29] & DFA, DMA & DFA exceeds DMA \\
\hline Teverovsky et al. [62] & $\mathrm{R} / \mathrm{S}$ & Variety of shortcomings in the $\mathrm{R} / \mathrm{S}$ - analysis methodology are detected \\
\hline Lo [14] & $\mathrm{R} / \mathrm{S}$ (modified) & $\begin{array}{l}\text { Using the modified R/S - analysis methodology short-term memory is } \\
\text { detected instead of long-term memory. In general results evidence } \\
\text { in favour of the EMH. }\end{array}$ \\
\hline
\end{tabular}

\footnotetext{
* rescaled range analysis (R/S), generalized Hurst exponent approach (GHE), detrended moving average (DMA), detrended fluctuation analysis (DFA), multifractal generalization (MF-DFA)
} 


\section{Appendix 2. Hurst exponent in financial data: general overview}

Table A2. Hurst exponent calculation methodology applied for financial data.

\begin{tabular}{|c|c|c|c|}
\hline Author & Methodology & Data and period & Results \\
\hline Barunik et al. [63] & $\begin{array}{l}\text { R/S, GHE, } \\
\text { DMA, } \\
\text { DFA, } \\
\text { MF-DFA }\end{array}$ & $\begin{array}{r}\text { S\&P } 500 \text { Index } \\
(1983-2009)\end{array}$ & $\begin{array}{l}\text { GHE methodology provides better } \\
\text { results. R/S-analysis is stable for the } \\
\text { fat tails in data. MF- DFA and DMA are } \\
\text { inappropriate for the data with fat tails. }\end{array}$ \\
\hline Hja Su and LinYang [64] & $R / S$ & $\begin{array}{l}\text { Chinese Stock Market } \\
(1991-2001)\end{array}$ & $\begin{array}{l}\text { Short-term memory is detected but there } \\
\text { is no long-term dependencies in data }\end{array}$ \\
\hline Greene and Fielitz [3] & $R / S$ & US Stock Market (NYSE) & $\begin{array}{l}\text { Substantial proofs in favour of long-term } \\
\text { dependency }\end{array}$ \\
\hline Peters [26] and Peters [27] & $R / S$ & $\begin{array}{l}\text { S\&P } 500 \text { Index } \\
(1950-1988)\end{array}$ & $\begin{array}{l}\text { Hurst exponent equals } 0.78 \text { for the monthly } \\
\text { returns in } S \& P 500 \text { data. Convincing } \\
\text { evidences in favour of persistence in } \\
\text { data }\end{array}$ \\
\hline Corazza and Malliaris [21]. & $\mathrm{R} / \mathrm{S}$ & FOREX (1972-1994) & $\begin{array}{l}\text { Hurst exponent statistically differs from } 0.5 \\
\text { and in not stable in time }\end{array}$ \\
\hline Glenn [22] & $R / S$ & NASDAQ & $\begin{array}{l}\text { Hurst exponent for the daily data equals } \\
0.59 \text { but increases to } 0.87 \text { for the yearly } \\
\text { data }\end{array}$ \\
\hline Lento, Camillo [65] & $\mathrm{R} / \mathrm{S}$ & DJIA (1998-2008) & $\begin{array}{l}\text { Hurst exponent can identify the persistence } \\
\text { properties in data }\end{array}$ \\
\hline Onali et al. [66] & $\mathrm{R} / \mathrm{S}$ & $\begin{array}{l}\text { Mibtel (Italy) and } \\
\text { PX-Glob (Czech } \\
\text { Republic). }\end{array}$ & $\begin{array}{l}\text { Evidences in favour of the long-term } \\
\text { dependences in logarithm returns }\end{array}$ \\
\hline Serletis and Rosenberg [67] & $\mathrm{R} / \mathrm{S}$ & US Stock Market & No long-term dependencies \\
\hline Batten et al. [18] & $R / S$ & $\begin{array}{l}\text { Nikkei Index } \\
\quad(1980-2000)\end{array}$ & No long memory is detected \\
\hline Berg et al. [16] & $R / S$ & $\begin{array}{l}\text { Swedish Stock Market } \\
\quad(1980-1995)\end{array}$ & $\begin{array}{l}\text { Evidences in favour of the long-term } \\
\text { dependences in data are doubtful. }\end{array}$ \\
\hline Lo [14] & $\begin{array}{l}\text { R/S } \\
\text { (modified) }\end{array}$ & $\begin{array}{l}\text { US Stock Market } \\
\quad(1872-1986)\end{array}$ & No long-term dependencies \\
\hline Ding et al. [68] & $\mathrm{R} / \mathrm{S}$ & S\&P 500 Index & Evidences of long-term memory in returns \\
\hline Jacobsen and Ben [15] & $\mathrm{R} / \mathrm{S}$ & $\begin{array}{l}\text { European, U.S.A. and } \\
\text { Japan Stock Markets }\end{array}$ & No long-memory is detected \\
\hline Barkoulas et al. [34] & $\mathrm{R} / \mathrm{S}$ & Futures markets & $\begin{array}{l}\text { Stable evidences of long-term memory in } \\
\text { futures returns }\end{array}$ \\
\hline Crato and Ray [17] & $R / S$ & $\begin{array}{l}\text { Commodities } \\
\quad(1977-1997)\end{array}$ & $\begin{array}{l}\text { No persistence in data case of returns, } \\
\text { but convincing evidences of long-term } \\
\text { memory in volatility. }\end{array}$ \\
\hline
\end{tabular}




\section{Appendix 3. Hurst exponent interval characteristics}

Table A3. Hurst exponent interval characteristics.

\begin{tabular}{|c|c|c|c|c|c|}
\hline Interval & Hypothesis & Distribution & «Memory» of series & Type of process & Trading strategies \\
\hline $0 \leq H<0.5$ & $\begin{array}{l}\text { Data is fractal, FMH } \\
\text { is confirmed }\end{array}$ & $\begin{array}{l}\text { 'Heavy tails' of } \\
\text { distribution }\end{array}$ & $\begin{array}{l}\text { Antipersistent } \\
\text { series, negative } \\
\text { correlation in } \\
\text { instruments } \\
\text { value changes }\end{array}$ & $\begin{array}{l}\text { Pink noise with } \\
\text { frequent } \\
\text { changes in } \\
\text { direction of price } \\
\text { movement }\end{array}$ & $\begin{array}{l}\text { Trading in } \\
\text { the market } \\
\text { is more } \\
\text { risky for an } \\
\text { individual } \\
\text { participant }\end{array}$ \\
\hline$H=0.5$ & $\begin{array}{l}\text { Data is random, } \\
\text { EMH is } \\
\text { confirmed }\end{array}$ & $\begin{array}{l}\text { Movement of } \\
\text { asset prices is } \\
\text { an example of } \\
\text { the random } \\
\text { Brownian } \\
\text { motion (Wiener } \\
\text { process), } \\
\text { time series } \\
\text { are normally } \\
\text { distributed }\end{array}$ & $\begin{array}{l}\text { Lack of correlation } \\
\text { in changes in } \\
\text { value of assets } \\
\text { (memory of } \\
\text { series) }\end{array}$ & $\begin{array}{l}\text { White noise of } \\
\text { independent } \\
\text { random process }\end{array}$ & $\begin{array}{l}\text { Traders cannot } \\
\text { 'beat' the } \\
\text { market with } \\
\text { the use of } \\
\text { any trading } \\
\text { strategy }\end{array}$ \\
\hline $0.5<H \leq 1$ & $\begin{array}{l}\text { Data is fractal, FMH } \\
\text { is confirmed }\end{array}$ & $\begin{array}{c}\text { 'Heavy tails' of } \\
\text { distribution }\end{array}$ & $\begin{array}{l}\text { Persistent series, } \\
\text { positive } \\
\text { correlation } \\
\text { within changes } \\
\text { in the value of } \\
\text { assets }\end{array}$ & Black noise & $\begin{array}{l}\text { Trend is } \\
\text { present in } \\
\text { the market }\end{array}$ \\
\hline
\end{tabular}

\section{Appendix 4. R/S analysis}

Table A4. Results of the R/S analysis for the different financial markets, 2004-2016.

\begin{tabular}{llll}
\hline Financial market & Instrument & Return & Volatility \\
\hline \multirow{4}{*}{ FOREX } & (i) Daily data & & \\
& EURUSD & 0.55 & 0.48 \\
Stock market & USDJPY & 0.56 & 0.43 \\
& Dow Jones & 0.51 & 0.46 \\
& FTSE & 0.47 & 0.47 \\
& NIKKEI & 0.54 & 0.68 \\
& MICEX & 0.55 & 0.46 \\
& PFTS & 0.67 & 0.46 \\
Commodities & Oil & 0.57 & 0.62 \\
& Gold & 0.54 & 0.66 \\
& (ii) Weekly data & & \\
FOREX & EURUSD & 0.56 & 0.36 \\
Stock market & USDJPY & 0.57 & 0.43 \\
& Dow Jones & 0.56 & 0.53 \\
& FTSE & 0.52 & 0.56 \\
Commodities & NIKKEI & 0.57 & 0.51 \\
& Oil & 0.64 & 0.46 \\
& Gold & 0.56 & 0.40 \\
& (iii) Monthly data & & \\
FOREX & EURUSD & 0.55 & 0.38 \\
Stock market & USDJPY & 0.66 & 0.42 \\
& Dow Jones & 0.73 & 0.63 \\
& FTSE & 0.74 & 0.46 \\
& NIKKEI & 0.68 & 0.57 \\
& MICEX & 0.61 & 0.42 \\
Commodities & PFTS & 0.73 & 0.53 \\
& Oil & 0.57 & 0.34 \\
& Gold & 0.63 & 0.41 \\
\hline
\end{tabular}




\section{Appendix 5. Fractional integration. Parametric method}

Table A5. Estimates of $d$ using uncorrelated (white noise) errors.

\begin{tabular}{|c|c|c|c|}
\hline Financial market & Instrument & Return & Volatility \\
\hline \multicolumn{4}{|c|}{ (i) Daily data } \\
\hline \multirow[t]{2}{*}{ FOREX } & EURUSD & $-0.01(-0.03,0.01)$ & $0.26(0.25,0.28)$ \\
\hline & USDJPY & $-0.03(-0.05,-0.01)$ & $0.25(0.23,0.27)$ \\
\hline \multirow[t]{5}{*}{ Stock market } & Dow Jones & $-0.08(-0.10,-0.06)$ & $0.36(0.34,0.38)$ \\
\hline & FTSE & $-0.15(-0.17,-0.13)$ & $0.33(0.30,0.34)$ \\
\hline & NIKKEI & $-0.05(-0.08,-0.03)$ & $0.34(0.32,0.36)$ \\
\hline & MICEX & $-0.02(-0.04,0.00)$ & $0.39(0.37,0.41)$ \\
\hline & PFTS & $0.10(0.08,0.12)$ & \\
\hline \multirow[t]{2}{*}{ Commodities } & Oil & $-0.01(-0.03,0.01)$ & $0.26(0.24,0.27)$ \\
\hline & Gold & $-0.02(-0.04,0.00)$ & $0.27(0.26,0.29)$ \\
\hline \multicolumn{4}{|c|}{ (ii) Weekly data } \\
\hline \multirow[t]{2}{*}{ FOREX } & EURUSD & $0.01(-0.03,0.06)$ & $0.31(0.28,0.35)$ \\
\hline & USDJPY & $-0.03(-0.06,0.02)$ & $0.26(0.23,0.30)$ \\
\hline \multirow[t]{3}{*}{ Stock market } & Dow Jones & $-0.06(-0.10,-0.01)$ & $0.39(0.35,0.44)$ \\
\hline & FTSE & $-0.12(-0.15,-0.07)$ & $0.42(0.38,0.48)$ \\
\hline & NIKKEI & $-0.04(-0.08,0.00)$ & $0.37(0.33,0.42)$ \\
\hline \multirow[t]{2}{*}{ Commodities } & Oil & $0.01(-0.03,0.06)$ & $0.35(0.32,0.38)$ \\
\hline & Gold & $-0.02(-0.05,0.02)$ & $0.60(0.55,0.66)$ \\
\hline \multicolumn{4}{|c|}{ (iii) Monthly data } \\
\hline \multirow[t]{2}{*}{ FOREX } & EURUSD & $-0.01(-0.09,0.10)$ & $0.30(0.24,0.38)$ \\
\hline & USDJPY & $0.02(-0.06,0.12)$ & $0.28(0.20,0.39)$ \\
\hline \multirow[t]{5}{*}{ Stock market } & Dow Jones & $0.03(-0.07,0.15)$ & $0.28(0.20,0.39)$ \\
\hline & FTSE & $0.02(-0.07,0.12)$ & $0.29(0.21,0.40)$ \\
\hline & NIKKEI & $0.08(-0.01,0.21)$ & $0.31(0.23,0.42)$ \\
\hline & MICEX & $0.11(0.01,0.26)$ & $0.47(0.39,0.58)$ \\
\hline & PFTS & $0.21(0.08,0.41)$ & \\
\hline \multirow[t]{2}{*}{ Commodities } & Oil & $-0.01(-0.10,0.11)$ & $0.45(0.39,0.54)$ \\
\hline & Gold & $-0.07(-0.14,0.01)$ & $0.49(0.42,0.60)$ \\
\hline
\end{tabular}




\section{Appendix 6. Semiparametric method}

Table A6. Estimates of $d$ for the return series. Semiparametric method.

\begin{tabular}{|c|c|c|c|c|c|c|c|c|c|c|}
\hline & & \multicolumn{9}{|c|}{ (i) Daily data } \\
\hline & & 56 & 58 & 60 & 62 & 64 & 66 & 68 & 70 & 72 \\
\hline \multirow[t]{2}{*}{ FOREX } & Euro & 0.015 & 0.005 & 0.016 & 0.016 & 0.013 & -0.008 & -0.001 & -0.006 & 0.000 \\
\hline & DJPY & 0.129 & 0.107 & 0.112 & 0.111 & 0.104 & 0.121 & 0.110 & 0.101 & 0.102 \\
\hline \multirow[t]{4}{*}{ Stock Market } & $D \& J$ & -0.041 & -0.037 & -0.030 & -0.025 & -0.009 & -0.020 & -0.020 & -0.009 & -0.001 \\
\hline & FTSE & -0.214 & -0.228 & -0.228 & -0.215 & -0.233 & -0.240 & -0.240 & -0.247 & -0.237 \\
\hline & Nikkei & 0.010 & 0.002 & 0.004 & 0.002 & 0.009 & 0.004 & 0.001 & 0.009 & 0.022 \\
\hline & MICEX & 0.113 & 0.107 & 0.078 & 0.082 & 0.079 & 0.051 & 0.059 & 0.070 & 0.073 \\
\hline \multirow{4}{*}{ Comm. } & Oil & -0.040 & -0.036 & -0.036 & -0.038 & -0.036 & -0.030 & -0.030 & -0.032 & -0.031 \\
\hline & Gold & 0.042 & 0.018 & 0.015 & -0.020 & -0.054 & -0.043 & -0.063 & -0.076 & -0.075 \\
\hline & & \multicolumn{9}{|c|}{ (ii) Weekly data } \\
\hline & & 22 & 24 & 26 & 28 & 30 & 32 & 34 & 36 & 38 \\
\hline \multirow[t]{2}{*}{ FOREX } & Euro & 0.047 & 0.001 & 0.014 & 0.020 & 0.008 & 0.042 & 0.027 & 0.025 & 0.032 \\
\hline & DJPY & -0.030 & -0.015 & -0.014 & 0.014 & 0.033 & 0.063 & 0.080 & 0.095 & 0.130 \\
\hline \multirow[t]{3}{*}{ Stock Market } & $D \& J$ & 0.091 & 0.029 & 0.072 & 0.102 & 0.121 & 0.079 & 0.044 & 0.080 & 0.063 \\
\hline & FTSE & 0.207 & 0.122 & 0.074 & 0.115 & 0.067 & 0.093 & 0.073 & 0.061 & -0.009 \\
\hline & Nikkei & 0.014 & 0.050 & 0.046 & 0.082 & 0.073 & 0.116 & 0.091 & 0.103 & 0.125 \\
\hline \multirow[t]{4}{*}{ Comm. } & Oil & -0.069 & -0.042 & -0.013 & 0.032 & 0.033 & 0.050 & 0.000 & 0.004 & -0.009 \\
\hline & Gold & 0.097 & 0.106 & 0.098 & 0.107 & 0.141 & 0.105 & 0.067 & 0.056 & 0.009 \\
\hline & & \multicolumn{9}{|c|}{ (iii) Monthly data } \\
\hline & & 11 & 12 & 13 & 14 & 15 & 16 & 17 & 18 & 19 \\
\hline \multirow[t]{2}{*}{ FOREX } & Euro & -0.121 & -0.114 & -0.066 & -0.059 & -0.045 & -0.019 & 0.025 & 0.072 & 0.089 \\
\hline & DJPY & 0.306 & 0.285 & 0.262 & 0.260 & 0.220 & 0.208 & 0.129 & -0.004 & -0.009 \\
\hline \multirow[t]{4}{*}{ Stock Market } & $D \& J$ & 0.127 & 0.120 & 0.132 & -0.100 & -0.035 & 0.015 & -0.004 & -0.018 & 0.023 \\
\hline & FTSE & 0.265 & 0.124 & 0.058 & 0.062 & 0.019 & 0.040 & 0.047 & 0.090 & 0.108 \\
\hline & Nikkei & 0.076 & 0.035 & 0.039 & 0.002 & 0.049 & 0.101 & 0.002 & -0.037 & -0.020 \\
\hline & MICEX & -0.098 & -0.082 & -0.057 & -0.084 & -0.045 & -0.019 & -0.036 & -0.054 & -0.066 \\
\hline \multirow[t]{2}{*}{ Comm. } & Oil & -0.085 & -0.103 & -0.054 & -0.101 & -0.070 & -0.087 & -0.114 & -0.096 & -0.151 \\
\hline & Gold & 0.175 & 0.222 & 0.215 & 0.147 & 0.155 & 0.111 & 0.102 & 0.097 & 0.101 \\
\hline
\end{tabular}


Table A7. Estimates of $d$ for the volatility series. Semiparametric method.

\begin{tabular}{|c|c|c|c|c|c|c|c|c|c|c|}
\hline & & \multicolumn{9}{|c|}{ (i) Daily data } \\
\hline & & 56 & 58 & 60 & 62 & 64 & 66 & 68 & 70 & 72 \\
\hline \multirow[t]{2}{*}{ FOREX } & Euro & 0.500 & 0.500 & 0.500 & 0.500 & 0.500 & 0.500 & 0.500 & 0.500 & 0.500 \\
\hline & DJPY & 0.448 & 0.462 & 0.483 & 0.493 & 0.500 & 0.500 & 0.500 & 0.500 & 0.500 \\
\hline \multirow[t]{4}{*}{ Stock Market } & $D \& J$ & 0.500 & 0.500 & 0.500 & 0.500 & 0.500 & 0.500 & 0.500 & 0.500 & 0.500 \\
\hline & FTSE & 0.500 & 0.500 & 0.500 & 0.500 & 0.500 & 0.500 & 0.500 & 0.500 & 0.500 \\
\hline & Nikkei & 0.500 & 0.500 & 0.500 & 0.500 & 0.500 & 0.500 & 0.500 & 0.500 & 0.500 \\
\hline & MICEX & 0.500 & 0.500 & 0.500 & 0.500 & 0.500 & 0.500 & 0.500 & 0.500 & 0.500 \\
\hline \multirow[t]{4}{*}{ Comm. } & Oil & 0.500 & 0.500 & 0.500 & 0.500 & 0.500 & 0.500 & 0.500 & 0.500 & 0.500 \\
\hline & Gold & 0.500 & 0.500 & 0.500 & 0.500 & 0.500 & 0.500 & 0.500 & 0.500 & 0.500 \\
\hline & & \multicolumn{9}{|c|}{ (ii) Weekly data } \\
\hline & & 22 & 24 & 26 & 28 & 30 & 32 & 34 & 36 & 38 \\
\hline \multirow[t]{2}{*}{ FOREX } & Euro & 0.500 & 0.500 & 0.500 & 0.500 & 0.500 & 0.500 & 0.500 & 0.500 & 0.500 \\
\hline & DJPY & 0.403 & 0.444 & 0.429 & 0.448 & 0.443 & 0.375 & 0.376 & 0.396 & 0.426 \\
\hline \multirow[t]{3}{*}{ Stock Market } & D\&J & 0.362 & 0.365 & 0.392 & 0.373 & 0.409 & 0.401 & 0.399 & 0.400 & 0.412 \\
\hline & FTSE & 0.417 & 0.421 & 0.420 & 0.411 & 0.403 & 0.437 & 0.429 & 0.446 & 0.447 \\
\hline & Nikkei & 0.450 & 0.461 & 0.499 & 0.444 & 0.449 & 0.434 & 0.449 & 0.444 & 0.418 \\
\hline \multirow[t]{4}{*}{ Comm. } & Oil & 0.500 & 0.500 & 0.500 & 0.500 & 0.500 & 0.500 & 0.500 & 0.500 & 0.500 \\
\hline & Gold & 0.500 & 0.500 & 0.500 & 0.500 & 0.500 & 0.500 & 0.500 & 0.500 & 0.500 \\
\hline & & \multicolumn{9}{|c|}{ (iii) Monthly data } \\
\hline & & 11 & 12 & 13 & 14 & 15 & 16 & 17 & 18 & 19 \\
\hline \multirow[t]{2}{*}{ FOREX } & Euro & 0.484 & 0.448 & 0.436 & 0.461 & 0.500 & 0.500 & 0.500 & 0.483 & 0.475 \\
\hline & DJPY & 0.306 & 0.285 & 0.262 & 0.260 & 0.220 & 0.208 & 0.129 & -0.004 & -0.009 \\
\hline \multirow[t]{4}{*}{ Stock Market } & $D \& J$ & 0.391 & 0.362 & 0.316 & 0.306 & 0.331 & 0.305 & 0.326 & 0.308 & 0.337 \\
\hline & JTSE & 0.065 & -0.120 & -0.058 & -0.062 & -0.019 & 0.040 & 0.047 & 0.090 & 0.108 \\
\hline & Nikkei & 0.076 & 0.035 & -0.039 & 0.002 & 0.049 & 0.101 & 0.002 & -0.037 & -0.020 \\
\hline & MICEX & -0.098 & -0.082 & -0.057 & -0.084 & -0.045 & -0.019 & -0.036 & -0.054 & -0.066 \\
\hline \multirow[t]{2}{*}{ Comm. } & Oil & -0.085 & -0.103 & -0.054 & -0.101 & -0.070 & -0.087 & -0.114 & -0.096 & -0.151 \\
\hline & Gold & 0.175 & 0.222 & 0.215 & 0.147 & 0.155 & 0.111 & 0.102 & 0.097 & 0.101 \\
\hline
\end{tabular}

\section{Appendix 7. Descriptive statistic of the data}

Table A8. Descriptive statistics of the data: EURUSD.

\begin{tabular}{|c|c|c|c|c|c|c|}
\hline Parameter & Daily returns & Daily volatility & Weekly returns & Weekly volatility & Monthly returns & Monthly volatility \\
\hline Mean & 0.0000 & 0.0097 & 0.0002 & 0.0222 & 0.0011 & 0.0465 \\
\hline Standard Error & 0.0001 & 0.0001 & 0.0005 & 0.0003 & 0.0021 & 0.0015 \\
\hline Median & 0.0001 & 0.0088 & 0.0004 & 0.0202 & 0.0017 & 0.0434 \\
\hline Mode & 0.0000 & 0.0059 & 0.0000 & $\mathrm{n} / \mathrm{a}$ & $\mathrm{n} / \mathrm{a}$ & $\mathrm{n} / \mathrm{a}$ \\
\hline Standard Deviation & 0.0064 & 0.0049 & 0.0141 & 0.0102 & 0.0300 & 0.0214 \\
\hline Variance & 0.0000 & 0.0000 & 0.0002 & 0.0001 & 0.0009 & 0.0005 \\
\hline Kurtosis & 1.5740 & 6.3915 & 0.8658 & 7.1626 & 1.0614 & 7.5183 \\
\hline Skewness & 0.0831 & 1.7835 & -0.1849 & 1.8486 & -0.0981 & 1.9754 \\
\hline Range & 0.0615 & 0.0507 & 0.1097 & 0.0942 & 0.1981 & 0.1583 \\
\hline Minimum & -0.0266 & 0.0000 & -0.0585 & 0.0051 & -0.0983 & 0.0144 \\
\hline Maximum & 0.0349 & 0.0507 & 0.0512 & 0.0993 & 0.0998 & 0.1726 \\
\hline Sum & 0.1740 & 42.4456 & 0.1662 & 19.4722 & 0.2276 & 9.4354 \\
\hline Number & 4381 & 4381 & 879 & 879 & 203 & 203 \\
\hline
\end{tabular}


Table A9. Descriptive statistics of the data: USDJPY.

\begin{tabular}{|c|c|c|c|c|c|c|}
\hline Parameter & Daily returns & Daily volatility & Weekly returns & Weekly volatility & Monthly returns & Monthly volatility \\
\hline Mean & 0.0000 & 0.0096 & 0.0001 & 0.0220 & 0.0004 & 0.0466 \\
\hline Standard Error & 0.0001 & 0.0001 & 0.0005 & 0.0004 & 0.0020 & 0.0014 \\
\hline Median & 0.0000 & 0.0086 & 0.0003 & 0.0197 & 0.0012 & 0.0432 \\
\hline Mode & 0.0000 & 0.0118 & 0.0000 & 0.0145 & $\mathrm{n} / \mathrm{a}$ & $\mathrm{n} / \mathrm{a}$ \\
\hline Standard Deviation & 0.0065 & 0.0055 & 0.0142 & 0.0112 & 0.0285 & 0.0203 \\
\hline Variance & 0.0000 & 0.0000 & 0.0002 & 0.0001 & 0.0008 & 0.0004 \\
\hline Kurtosis & 4.0465 & 25.0610 & 1.0404 & 12.4680 & 0.3043 & 7.3183 \\
\hline Skewness & -0.0729 & 3.3258 & -0.2326 & 2.4932 & 0.1997 & 1.9213 \\
\hline Range & 0.0912 & 0.0781 & 0.1191 & 0.1214 & 0.1564 & 0.1563 \\
\hline Minimum & -0.0377 & 0.0014 & -0.0726 & 0.0050 & -0.0710 & 0.0154 \\
\hline Maximum & 0.0535 & 0.0795 & 0.0465 & 0.1264 & 0.0853 & 0.1717 \\
\hline Sum & 0.1004 & 41.9403 & 0.0983 & 19.3722 & 0.0911 & 9.4625 \\
\hline Number & 4381 & 4381 & 879 & 879 & 203 & 203 \\
\hline
\end{tabular}

Table A10. Descriptive statistics of the data: NIKKEI.

\begin{tabular}{|c|c|c|c|c|c|c|}
\hline Parameter & Daily returns & Daily volatility & Weekly returns & Weekly volatility & Monthly returns & Monthly volatility \\
\hline Mean & 0.0003 & 0.0198 & 0.0008 & 0.0464 & 0.0028 & 0.1019 \\
\hline Standard Error & 0.0003 & 0.0003 & 0.0011 & 0.0012 & 0.0041 & 0.0050 \\
\hline Median & 0.0004 & 0.0160 & 0.0043 & 0.0401 & 0.0057 & 0.0879 \\
\hline Mode & 0.0000 & 0.0120 & 0.0000 & 0.0325 & $\mathrm{n} / \mathrm{a}$ & $\mathrm{n} / \mathrm{a}$ \\
\hline Standard Deviation & 0.0156 & 0.0175 & 0.0330 & 0.0337 & 0.0572 & 0.0695 \\
\hline Variance & 0.0002 & 0.0003 & 0.0011 & 0.0011 & 0.0033 & 0.0048 \\
\hline Kurtosis & 15.7416 & 46.5907 & 6.8953 & 50.2243 & 0.7655 & 28.5045 \\
\hline Skewness & 0.5381 & 4.9174 & -0.7316 & 5.4022 & -0.4030 & 3.9987 \\
\hline Range & 0.2956 & 0.3118 & 0.4546 & 0.4709 & 0.3887 & 0.6915 \\
\hline Minimum & -0.0984 & 0.0005 & -0.2716 & 0.0047 & -0.2359 & 0.0060 \\
\hline Maximum & 0.1972 & 0.3122 & 0.1831 & 0.4756 & 0.1528 & 0.6975 \\
\hline Sum & 0.8022 & 62.5504 & 0.6514 & 37.9725 & 0.5482 & 19.8612 \\
\hline Number & 3154 & 3154 & 818 & 818 & 195 & 195 \\
\hline
\end{tabular}

Table A11. Descriptive statistics of the data: FTSE.

\begin{tabular}{|c|c|c|c|c|c|c|}
\hline Parameter & Daily returns & Daily volatility & Weekly returns & Weekly volatility & Monthly returns & Monthly volatility \\
\hline Mean & 0.0002 & 0.0141 & 0.0004 & 0.0345 & 0.0012 & 0.0735 \\
\hline Standard Error & 0.0003 & 0.0002 & 0.0008 & 0.0009 & 0.0028 & 0.0039 \\
\hline Median & 0.0000 & 0.0114 & 0.0013 & 0.0284 & 0.0057 & 0.0586 \\
\hline Mode & 0.0000 & 0.0000 & 0.0000 & 0.0360 & $\mathrm{n} / \mathrm{a}$ & $\mathrm{n} / \mathrm{a}$ \\
\hline Standard Deviation & 0.0201 & 0.0100 & 0.0252 & 0.0254 & 0.0403 & 0.0553 \\
\hline Variance & 0.0004 & 0.0001 & 0.0006 & 0.0006 & 0.0016 & 0.0031 \\
\hline Kurtosis & 924.4408 & 13.8449 & 6.6587 & 12.7830 & 0.4735 & 7.5889 \\
\hline Skewness & 14.0954 & 2.7968 & -0.2090 & 2.7094 & -0.4276 & 2.3495 \\
\hline Range & 1.3665 & 0.1128 & 0.3211 & 0.2583 & 0.2128 & 0.3844 \\
\hline Minimum & -0.5218 & 0.0000 & -0.1762 & 0.0021 & -0.1196 & 0.0000 \\
\hline Maximum & 0.8447 & 0.1128 & 0.1450 & 0.2604 & 0.0932 & 0.3844 \\
\hline Sum & 0.7254 & 47.8199 & 0.3526 & 30.7696 & 0.2317 & 14.7035 \\
\hline Number & 3388 & 3388 & 891 & 891 & 200 & 200 \\
\hline
\end{tabular}


Table A12. Descriptive statistics of the data: Dow Jones Index.

\begin{tabular}{|c|c|c|c|c|c|c|}
\hline Parameter & Daily returns & Daily volatility & Weekly returns & Weekly volatility & Monthly returns & Monthly volatility \\
\hline Mean & 0.0002 & 0.0125 & 0.0009 & 0.0320 & -0.0018 & 0.0702 \\
\hline Standard Error & 0.0002 & 0.0002 & 0.0008 & 0.0008 & 0.0060 & 0.0037 \\
\hline Median & 0.0005 & 0.0097 & 0.0026 & 0.0261 & 0.0068 & 0.0564 \\
\hline Mode & $\mathrm{n} / \mathrm{a}$ & 0.0000 & 0.0000 & 0.0000 & $\mathrm{n} / \mathrm{a}$ & $\mathrm{n} / \mathrm{a}$ \\
\hline Standard Deviation & 0.0111 & 0.0103 & 0.0235 & 0.0241 & 0.0835 & 0.0517 \\
\hline Variance & 0.0001 & 0.0001 & 0.0006 & 0.0006 & 0.0070 & 0.0027 \\
\hline Kurtosis & 11.3513 & 27.1819 & 8.3437 & 30.7719 & 108.2486 & 9.8593 \\
\hline Skewness & 0.1458 & 4.1017 & -0.9886 & 4.0488 & -9.1049 & 2.6799 \\
\hline Range & 0.1939 & 0.1276 & 0.2948 & 0.3109 & 1.1060 & 0.3762 \\
\hline Minimum & -0.0825 & 0.0000 & -0.1955 & 0.0000 & -1.0000 & 0.0091 \\
\hline Maximum & 0.1114 & 0.1276 & 0.0994 & 0.3109 & 0.1060 & 0.3853 \\
\hline Sum & 0.7545 & 39.0534 & 0.7496 & 26.3724 & -0.3393 & 13.4128 \\
\hline Number & 3136 & 3136 & 826 & 826 & 191 & 191 \\
\hline
\end{tabular}

Table A13. Descriptive statistics of the data: MICEX.

\begin{tabular}{lcccccc}
\hline Parameter & Daily returns & Daily volatility & Weekly returns & Weekly volatility & Monthly returns & Monthly volatility \\
\hline Mean & 0.0007 & 0.0198 & $\mathrm{n} / \mathrm{a}$ & $\mathrm{n} / \mathrm{a}$ & $\mathrm{n} / \mathrm{a}$ & 0.1472 \\
Standard Error & 0.0004 & 0.0003 & $\mathrm{n} / \mathrm{a}$ & $\mathrm{n} / \mathrm{a}$ & 0.0061 & 0.0085 \\
Median & 0.0011 & 0.0162 & $\mathrm{n} / \mathrm{a}$ & $\mathrm{n} / \mathrm{a}$ & 0.0221 & 0.1118 \\
Mode & 0.0000 & 0.0000 & $\mathrm{n} / \mathrm{a}$ & $\mathrm{n} / \mathrm{a}$ & $\mathrm{n} / \mathrm{a}$ & $\mathrm{n} / \mathrm{a}$ \\
Standard Deviation & 0.0211 & 0.0201 & $\mathrm{n} / \mathrm{a}$ & $\mathrm{n} / \mathrm{a}$ & 0.0854 & 0.1201 \\
Variance & 0.0004 & 0.0004 & $\mathrm{n} / \mathrm{a}$ & $\mathrm{n} / \mathrm{a}$ & 0.0073 & 0.0144 \\
Kurtosis & 20.8823 & 29.8782 & $\mathrm{n} / \mathrm{a}$ & $\mathrm{n} / \mathrm{a}$ & 1.2617 & 27.5782 \\
Skewness & 0.4292 & 3.8042 & $\mathrm{n} / \mathrm{a}$ & $\mathrm{n} / \mathrm{a}$ & -0.1533 & 4.3051 \\
Range & 0.4736 & 0.3174 & $\mathrm{n} / \mathrm{a}$ & $\mathrm{n} / \mathrm{a}$ & 0.6177 & 1.0932 \\
Minimum & -0.1866 & 0.0000 & $\mathrm{n} / \mathrm{a}$ & $\mathrm{n} / \mathrm{a}$ & -0.2877 & 0.0385 \\
Maximum & 0.2869 & 0.3174 & $\mathrm{n} / \mathrm{a}$ & $\mathrm{n} / \mathrm{a}$ & 0.3300 & 1.1317 \\
Sum & 2.5331 & 81.2557 & $\mathrm{n} / \mathrm{a}$ & $\mathrm{n} / \mathrm{a}$ & 3.1295 & 29.1379 \\
Number & 3378 & 3378 & $\mathrm{n} / \mathrm{a}$ & $\mathrm{n} / \mathrm{a}$ & 198 & 198 \\
\hline
\end{tabular}

Table A14. Descriptive statistics of the data: PFTS.

\begin{tabular}{lcccccc}
\hline Parameter & Daily returns & \multicolumn{1}{c}{ Daily volatility } & Weekly returns & Weekly volatility & Monthly returns & Monthly volatility \\
\hline Mean & 0.0006 & 0.0270 & $\mathrm{n} / \mathrm{a}$ & $\mathrm{n} / \mathrm{a}$ & $\mathrm{n} / \mathrm{a}$ & 0.0235 \\
Standard Error & 0.0003 & 0.0005 & $\mathrm{n} / \mathrm{a}$ & $\mathrm{n} / \mathrm{a}$ & 0.0110 & 0.0014 \\
Median & 0.0005 & 0.0219 & $\mathrm{n} / \mathrm{a}$ & $\mathrm{n} / \mathrm{a}$ & 0.0001 & 0.0207 \\
Mode & 0.0000 & $\mathrm{n} / \mathrm{a}$ & $\mathrm{n} / \mathrm{a}$ & $\mathrm{n} / \mathrm{a}$ & $\mathrm{n} / \mathrm{a}$ & $\mathrm{n} / \mathrm{a}$ \\
Standard Deviation & 0.0189 & 0.0193 & $\mathrm{n} / \mathrm{a}$ & $\mathrm{n} / \mathrm{a}$ & 0.1445 & 0.0127 \\
Variance & 0.0004 & 0.0004 & $\mathrm{n} / \mathrm{a}$ & $\mathrm{n} / \mathrm{a}$ & 0.0209 & 0.0002 \\
Kurtosis & 13.2777 & 19.9666 & $\mathrm{n} / \mathrm{a}$ & $\mathrm{n} / \mathrm{a}$ & 14.2695 & 0.9419 \\
Skewness & 0.5364 & 3.1713 & $\mathrm{n} / \mathrm{a}$ & $\mathrm{n} / \mathrm{a}$ & -1.5507 & 0.9848 \\
Range & 0.3725 & 0.2554 & $\mathrm{n} / \mathrm{a}$ & $\mathrm{n} / \mathrm{a}$ & 1.4949 & 0.0673 \\
Minimum & -0.1511 & 0.0014 & $\mathrm{n} / \mathrm{a}$ & $\mathrm{n} / \mathrm{a}$ & -1.0000 & 0.0014 \\
Maximum & 0.2215 & 0.2568 & $\mathrm{n} / \mathrm{a}$ & $\mathrm{n} / \mathrm{a}$ & 0.4949 & 0.0688 \\
Sum & 2.4088 & 45.6676 & $\mathrm{n} / \mathrm{a}$ & $\mathrm{n} / \mathrm{a}$ & 1.9927 & 1.9540 \\
Number & 1694 & 1694 & $\mathrm{n} / \mathrm{a}$ & $\mathrm{n} / \mathrm{a}$ & 172 & 172 \\
\hline
\end{tabular}


Table A15. Descriptive statistics of the data: gold.

\begin{tabular}{|c|c|c|c|c|c|c|}
\hline Parameter & Daily returns & Daily volatility & Weekly returns & Weekly volatility & Monthly returns & Monthly volatility \\
\hline Mean & 0.0004 & 0.0153 & 0.0011 & 0.0391 & 0.0092 & 0.0855 \\
\hline Standard Error & 0.0002 & 0.0002 & 0.0004 & 0.0007 & 0.0036 & 0.0032 \\
\hline Median & 0.0004 & 0.0129 & 0.0000 & 0.0339 & 0.0111 & 0.0740 \\
\hline Mode & 0.0000 & 0.0204 & 0.0000 & 0.0278 & $\mathrm{n} / \mathrm{a}$ & 0.0687 \\
\hline Standard Deviation & 0.0110 & 0.0105 & 0.0179 & 0.0221 & 0.0504 & 0.0452 \\
\hline Variance & 0.0001 & 0.0001 & 0.0003 & 0.0005 & 0.0025 & 0.0020 \\
\hline Kurtosis & 6.9611 & 14.0202 & 6.3365 & 9.5959 & 0.1155 & 9.6038 \\
\hline Skewness & 0.0186 & 2.6621 & 0.0237 & 2.4249 & -0.0121 & 2.4172 \\
\hline Range & 0.1872 & 0.1275 & 0.2327 & 0.2049 & 0.2886 & 0.3496 \\
\hline Minimum & -0.0728 & 0.0006 & -0.0929 & 0.0000 & -0.1589 & 0.0253 \\
\hline Maximum & 0.1144 & 0.1281 & 0.1398 & 0.2049 & 0.1298 & 0.3749 \\
\hline Sum & 1.8017 & 70.2224 & 1.7819 & 38.2117 & 1.8032 & 16.9288 \\
\hline Number & 4584 & 4584 & 978 & 978 & 198 & 198 \\
\hline
\end{tabular}

Table A16. Descriptive statistics of the data: oil.

\begin{tabular}{|c|c|c|c|c|c|c|}
\hline Parameter & Daily returns & Daily volatility & Weekly returns & Weekly volatility & Monthly returns & Monthly volatility \\
\hline Mean & 0.0003 & 0.0269 & 0.0016 & 0.0707 & 0.0086 & 0.1682 \\
\hline Standard Error & 0.0003 & 0.0003 & 0.0017 & 0.0014 & 0.0072 & 0.0069 \\
\hline Median & 0.0000 & 0.0234 & 0.0038 & 0.0617 & 0.0118 & 0.1504 \\
\hline Mode & 0.0000 & 0.0194 & 0.0000 & 0.0383 & $\mathrm{n} / \mathrm{a}$ & $\mathrm{n} / \mathrm{a}$ \\
\hline Standard Deviation & 0.0199 & 0.0192 & 0.0471 & 0.0397 & 0.1015 & 0.0966 \\
\hline Variance & 0.0004 & 0.0004 & 0.0022 & 0.0016 & 0.0103 & 0.0093 \\
\hline Kurtosis & 5.3857 & 9.0339 & 2.3106 & 7.4226 & 1.0793 & 5.7345 \\
\hline Skewness & 0.0644 & 2.0861 & -0.2703 & 2.1333 & -0.0153 & 1.9055 \\
\hline Range & 0.3179 & 0.2141 & 0.4519 & 0.3331 & 0.7087 & 0.6528 \\
\hline Minimum & -0.1532 & 0.0001 & -0.2364 & 0.0138 & -0.3371 & 0.0411 \\
\hline Maximum & 0.1646 & 0.2142 & 0.2155 & 0.3469 & 0.3716 & 0.6939 \\
\hline Sum & 1.7593 & 123.0184 & 1.2675 & 57.1341 & 1.7117 & 33.3054 \\
\hline Number & 4574 & 4574 & 808 & 808 & 198 & 198 \\
\hline
\end{tabular}

